Berkala Ilmu Perpustakaan dan Informasi, Vol. 17, No. 2, Desember 2021, Hal. 250-264 https://doi.org/10.22146/bip.v17i1.1828

ISSN 1693-7740 (Print), ISSN 2477-0361 (Online)

Tersedia online di https://journal.ugm.ac.id/v3/BIP

\title{
Relasi kuasa dalam pengembangan perangkat lunak open source perpustakaan perguruan tinggi di Bali
}

\author{
I Putu Suhartika ${ }^{1}$, Ni Putu Premierita Haryanti ${ }^{2}$ \\ ${ }^{1,2}$ Program Studi D3 Perpustakaan, Fakultas Ilmu Sosial dan Ilmu Politik, Universitas Udayana \\ ${ }^{1,2}$ Jl. P.B. Sudirman (Kampus Sudirman), Denpasar, Bali, 80232 \\ e-mail:suhartika@unud.ac.id,premierita@unud.ac.id
}

Naskah diterima: 10 Mei 2021, direvisi: 17 Agustus 2021, disetujui: 27 Oktober 2021

\begin{abstract}
ABSTRAK
Pendahuluan. Penelitian perangkat lunak open source dari aspek kritis masih jarang dilakukan mengingat selama ini penelitian tersebut lebih banyak mengkaji aspek teknis saja. Penelitian ini mengkaji proses, bentuk, ideologi, dan implikasi relasi kuasa dalam pengembangan perangkat lunak open source perpustakaan perguruan tinggi di Bali.

Metode penelitian. Metode penelitian yang digunakan adalah metode kajian budaya. Teknik pengumpulan data menggunakan wawancara secara semi-terstruktur, observasi, dan dokumentasi.

Data analisis. Penelitian ini menggunakan metode genealogi dan dekonstruksi. Metode ini berkaitan dengan teori relasi kuasa Foucault dan teori dekonstruksi Derrida.

Hasil dan Pembahasan. Proses relasi kuasa dalam pengembangan perangkat lunak open source perpustakaan perguruan tinggi di Bali tidak selamanya sejajar, namun juga dalam hubungan hegemonik. Relasi kuasa itu berlandaskan pengetahuan dan dipengaruhi oleh ideologi kepustakawanan, gratis, open source dan kapitalis. Relasi kuasa itu berimplikasi pada perpustakaan, pustakawan, dan pemustaka.

Kesimpulan dan Saran. Praktik relasi kuasa dalam pengembangan perangkat lunak open source perguruan tinggi di Bali tidak hanya berlandaskan pada pengetahuan tetapi juga kekuasaan hegemonik. Oleh karena itu, para aktor harus dapat meningkatkan keterampilan di bidang komunikasi.
\end{abstract}

Kata kunci: relasi kuasa; hegemoni; dekonstruksi; perangkat lunak open source

\section{ABSTRACT}

Introduction. Discussions on critical perspectives of open source software is limited as most studies focus on technical aspects. This study examines aspects of process, form, ideology, and implications of power relations in the development of open source software for university libraries in Bali, observed from non-technical aspects of the system.

Research methods. The paper used cultural studies method with semi-structured interviews, observation, and documentation as data collection methods.

Data analysis. This study used genealogy and deconstruction methods involving Foucault and Derrida theory.

Results and discussion. The process of power relations in the development of open source software for university libraries in Bali is not only comes in parallel, but also in hegemonic relations. These relations are based on knowledge and influenced by the ideology of librarianship, free, open source, and capitalist which have implications for libraries, librarians, and users.

Conclusion and suggestions. The practice of power relations in the development of open source software for university libraries in Bali occurred through knowledge and hegemonic power. Therefore, human resources shouldalso improve their communication skills.

Keywords: power relations; hegemony; deconstructions; open source software 


\section{A. PENDAHULUAN}

Perkembangan perpustakaan tidak dapat dilepaskan dengan peradaban manusia. Pada zaman dahulu, manusia sering meninggalkan "tanda" pada berbagai media sebagai sarana komunikasi di antara mereka dan generasi penerus. Tanda tersebut merupakan cikal bakal bahasa tertulis manusia, karena sebelumnya manusia melakukan komunikasi dengan menggunakan bahasa lisan atau bahasa isyarat. Seiring perkembangan peradaban tersebut, manusia mulai menemukan media tulis seperti "papyrus" atau "paper". Puncak perkembangan media tulis terjadi ketika ditemukan mesin cetak Gutenberg sekitar abad ke--16. Kehadiran percetakan handmade Gutenberg juga telah mengubah tradisi oral (lisan) menjadi tradisi menulis sekaligus perubahan pola komunikasi (lisan ke tulisan) masyarakat di belahan Eropa (Malik, 2013). Pencetakan buku dan dokumen lain secara besar-besaran terjadi setelah ditemukan mesin ini.

Fenomena seperti tersebut kembali terjadi ketika keberadaan buku mulai tergeser dengan kehadiran buku elektronik (e-book) dan sumber elektronik lainnya yang terdapat pada perpustakaan elektronik atau perpustakaan digital. Perpustakaan elektronik merupakan wujud dari transformasi teknologi informasi dan komunikasi di perpustakaan. Implementasi TIK (teknologi informasi dan komunikasi) di perpustakaan ini didukung oleh Pemerintah yang dituangkan melalui (Undang-Undang Republik Indonesia Nomor 43 Tahun 2007, 2007) tentang Perpustakaan. Pengembangan perpustakaan elektronik atau digital sebagai implementasi teknologi informasi dan komunikasi di perpustakaan diharapkan dapat berjalan dengan lebih optimal sesuai dengan peraturan pemerintah tersebut. Pengembangan tersebut dapat memudahkan akses informasi bagi pemustaka. Perpustakaan digital dibangun dalam rangka menciptakan, menghimpun, mengolah, menyajikan dan melestarikan rekaman-rekaman informasi berbantuan teknologi, serta jaringan informasi dengan tujuan untuk kemudahan akses dan pendayagunaan bersama sumber informasi (Mukhlis, 2016).
Perangkat lunak open source memberikan kontribusi terhadap perkembangan perpustakaan elektronik mengingat perangkat lunak tersebut dapat dijadikan solusi bagi perpustakaan yang belum mempunyai dana pengembangan software yang mencukupi. Namun demikian, pengembangan dan implentasi perangkat lunak open source tidak selalu berjalan seperti yang diharapkan mengingat adanya berbagai kepentingan dari para aktor yang terlibat dalam implementasi tersebut. Hal ini wajar mengingat keberadaan perangkat lunak open source tidak hanya dimaknai sebagai sebuah sistem perpustakaan elektronik yang semata-mata hanya digunakan secara teknis. Perangkat lunak open source juga merupakan entitas budaya yang dapat dimaknai sebagai ajang kontestasi kekuasaan bagi para aktor. Dibalik kontestasi kekuasaan tersebut bermain berbagai ideologi aktor, sehingga kepustakawanan sebagai sebuah ideologi perpustakaan mendapatkan perlawanan dari ideologi lainnya. Teori dan praktik kepustakawanan tidak dapat berjalan dengan optimal seiring dengan menguatnya pengaruh aktor yang terlibat dalam pengembangan dan implementasi software tersebut. Oleh karena itu, kegiatan tersebut sering menjadi lahan perebutan perhatian yang berimplikasi pada isu kekuasaan dan ideologi sektoral para aktor.

Sehubungan dengan hal tersebut, perangkat lunak open source tidak dapat dipahami hanya sebagai sistem perpustakaan berbasis elektronik. Perangkat lunak tersebut dapat juga dimaknai sebagai sebuah entitas dalam praktik sosial yang dapat melahirkan makna ruang tersendiri sesuai ideologi sektoral aktor. Pengembangan perangkat lunak open source dapat berimplikasi bagi perpustakaan itu sendiri seperti adanya hegemoni, kesenjangan, dan keterpinggiran perpustakaan.

Pengembangan dan implementasi perangkat lunak open source perpustakaan perguruan tinggi sebagai sebuah peristiwa budaya dalam masyarakat berkaitan erat dengan persoalan kekuasaan dan pengetahuan. Pada saat manusia menyadari pengetahuan yang dimilikinya, maka di sana akan muncul kuasa. Begitupun sebaliknya, kekuasaan tersebut 
seolah-olah tidak melekat pada dirinya ketika manusia tidak sadar dengan pengetahuannya. Dengan demikian, pengetahuan dan kekuasaan mempunyai hubungan yang erat dan tidak dapat terpisahkan. Dalam hal ini, kekuasaan dapat membentuk pengetahuan dan pengetahuan manusia dapat menghasilkan kekuasaan. Sehubungan dengan hal tersebut, perangkat lunak open source sangat terkait dengan kuasa dan pengetahuan. Ide pengembangan software merupakan pengetahuan yang dapat memproduksi kekuasaan, seperti kuasa merancang dan membangun sistem perpustakaan, dan membentuk hubungan atau relasi kuasa yang saling melengkapi.

Penelitian tentang perangkat lunak open source sudah banyak dilakukan, seperti yang dilakukan oleh Angreni \& Prastyaningsih (2019), Akhlis (2013) dan Gozali \& Lo (2012). Angreni (2019) membahas tentang ekosistem perangkat lunak open source. Akhlis (2013) mengkaji perangkat lunak open source untuk menunjang kegiatan akademik. Gozali (2012) membahas tentang pemanfaatan teknologi open source dalam pengembangan proses belajar jarak jauh di perguruan tinggi. Ketiga penelitian ini mengkaji perangkat lunak dari aspek teknis, seperti teknologi dan metode pengembangan perangkat lunak open source. Penelitian tersebut lebih banyak bersifat positivistik, yang difokuskan pada aspek teknis sistem. Sementara itu, penelitian tentang relasi kuasa dalam pengembangan perangkat lunak open source belum banyak dilakukan. Penelitian ini mengkaji perangkat lunak open source dalam perspektif kajian budaya (cultural studies). Penelitian kajian kritis ini diharapkan dapat membedakannya dengan penelitian sebelumnya. Tujuan penelitian ini adalah untuk membongkar sesuatu yang tersembunyi di balik praktik relasi kuasa dalam pengembangan perangkat lunak open source perpustakaan perguruan tinggi di Bali. Penelitian ini mengkaji proses, bentuk dan implikasi relasi kuasa, serta ideologi aktor dalam pengembangan perangkat lunak tersebut.

\section{B. TINJAUAN PUSTAKA}

Kekuasaan melekat pada setiap individu dan mempraktikkannya melalui sumber kekuasaan. Kekuasaan tersebut tidak terpusat melainkan tersebar pada pelbagai aspek kehidupan manusia. Setiap aktivitas manusia dalam praktik sosial selalu terkait dengan kekuasaan. Kekuasaan dapat menimbulkan suatu kepatuhan seseorang mengingat kekuasaan tersebut dapat dirasakan dan masuk lewat aspek psikologi individu, seperti perasaan. Kähkönen (2014) memberikan beberapa definisi kuasa yang dihubungkan dengan teori sosiologi atau teori pertukaran sosial yaitu untuk membuat seseorang melakukan sesuatu yang tidak akan dilakukan, kemampuan untuk memaksakan kehendak pada orang lain, dan kekuatan dalam jaringan penentu kekuasaan struktural. Kuasa dapat dikelompokkan dalam kuasa fisik (physical power) dan kuasa sosial (social power). Kuasa fisik mengacu pada kemampuan menggerakan objek terlihat, sedangkan kuasa sosial mengacu pada sesuatu yang tidak terlihat. Sehubungan dengan hal tersebut, kuasa dapat dimaknai dengan berbagai perspektif seperti perspektif ekonomi, politik, sosial, dan sebagainya.

Penelitian ini menggunakan teori relasi kuasa dan pengetahuan Foucault sebagai teori utama. Teori relasi kuasa dan pengetahuan Foucault, seorang filsuf Perancis, mengeksplorasi berbagai praktik diskursif yang mengkaitkan kekuasaan dalam pembentukan berbagai wacana sekaligus bekerjanya model kekuasaan/pengetahuan dalam praktik sosial. Foucault selalu mengaitkan 'kuasa' dengan 'pengetahuan' (power and knowledge). Sedemikian erat hubungan di antara keduanya sehingga tidak ada pengetahuan tanpa kuasa dan tidak ada pula kuasa tanpa pengetahuan. Hal ini menunjukkan pengetahuan dan kekuasaan selalu ada bersama-sama, karena kekuasaan dapat membentuk pengetahuan, dan pengetahuan dapat memproduksi kekuasaan.

Berdasarkan uraian tersebut, dapat dikatakan bahwa teori kuasa Faucault menempatkan pengetahuan daripada material atau fisik, sehingga setiap kelompok orang mempunyai kuasa atas apa yang melekat pada 
diri mereka. Walaupun demikian, relasi kuasa pengetahuan tidak selamanya dapat diterapkan dalam praktek sosial mengingat kekuasaan juga terkait dengan kekuatan fisik sehingga mempunyai makna dominasi dan represif yang dapat menciptakan kelas dalam struktur masyarakat. Sehubungan dengan tersebut, dapat dikatakan bahwa pengembangan perangkat lunak open source juga dapat dikatakan sebagai wacana yang di dalamnya mengandung relasi kuasa programmer dengan pengguna sistem.

Perangkat lunak (software) merupakan bagian sistem dalam komputer yang dapat menjalankan komputer melalui perintah program yang dimiliki. Komputer dapat dioperasikan oleh perangkat lunak sesuai dengan keinginan pengguna. Perangkat lunak dikelompokkan ke dalam beberapa kategori di antaranya perangkat lunak open source. Perangkat lunak open source adalah perangkat lunak yang dapat dikases secara terbuka dan bebas biaya, tanpa syarat, kode sumber terbuka, bebas untuk dimodifikasi, dan tidak ada proteksi dari pengembang. Kebanyakan perpustakaan perguruan tinggi menggunakan perangkat lunak open source sebagai sistem aplikasi perpustakaan elektronik mengingat perangkat lunak tersebut dapat didownload secara gratis dan dapat diubah sesuai dengan kebutuhannya. Suhartika (2018) menyatakan bahwa 83\% perpustakaan elektronik perguruan tinggi di Bali menggunakan perangkat lunak open source untuk sistem otomasi perpustakaan.

Pemilihan penggunaan perangkat lunak open source sebagai sistem otomasi perpustakaan tersebut di atas kebanyakan ditentukan oleh aktor internal perpustakaan. Persepsi gratis yang melekat pada perangkat lunak tersebut menjadi dorongan utama aktor internal perpustakaan dalam menggunakan software tersebut. Walaupun demikian, kebanyakan aktor tidak menyadari bahwa implementasi perangkat lunak tersebut memerlukan biaya seperti biaya instalasi, kastomisasi, dan pelatihan. Sejak awal tahun 2000-an, open source telah dikaitkan dengan berbagai cara ke model bisnis dan memberikan manfaat potensial dengan memperkenalkannya ke industri atau membangun model bisnis di sekitarnya (Müller et al., 2019). Perangkat lunak open source dapat dikerjakan oleh setiap orang yang ingin berkontribusi atas pengembangan perangkat lunak tersebut. Sehubungan dengan itu, perangkat lunak open source sering diluncurkan sesuai versinya, tergantung kebutuhan sistem pada saat diluncurkan. Perangkat lunak versi berikutnya merupakan update versi sebelumnya. Perangkat lunak open source mempunyai beberapa versi sebagai akomodasi kebutuhan pengguna pada periode tertentu. Komunitas merupakan kunci keberhasilan dari perangkat lunak open source.

Open source merupakan juga sebuah model bisnis dari suatu perangkat lunak. Perangkat lunak open source itu gratis dan dapat didownload secara bebas. Namun demikan, pengembangan perangkat lunak tersebut di perpustakaan sering memerlukan biaya seperti biaya instalasi, kastomisasi, dan pelatihan. Keberhasilan bisnis Open Source Software (OSS) ditentukan oleh karakteristik software seperti kekuatan produk, komunitas, pengembang, dan brand (merek). Semakin banyak komunitasnya semakin banyak perangkat lunak tersebut digunakan di masyarakat. Kebanyakan perpustakaan perguruan tinggi di Bali menggunakan perangkat lunak open source karena karakteristik dari perangkat tersebut.

Konsep hegemoni pertama kali diproduksi di Rusia pada tahun 1880 oleh Plekhanov. Konsep tersebut mengandung makna kepemimpinan hegemonik proletariat untuk menjatuhkan pemerintahan Tsar. Kata hegemoni itu berasal dari bahasa Yunani 'eugemonia' yang digunakan untuk menunjukkan dominasi posisi negara. Konsep Hegemoni Gramsci menunjukkan bahwa hegemoni dari kelas dominan dijalankan dalam masyarakat sipil dengan mengajak kelas-kelas yang berada di bawah (subordinate classes) untuk menerima nilai-nilai dan gagasan yang telah diambil oleh kelas yang dominan itu sendiri, dan dengan membangun jaringan kerjasama yang didasarkan atas nilai-nilai tersebut (Jainuri, 2014). Hegemoni Gramsci menekankan persetujuan dari kelas dibawahnya 
terhadap konsep kelas dominan. Hegemoni bukanlah hubungan dominasi dengan menggunakan kekuasaan, melainkan hubungan persetujuan dengan menggunakan kepemimpinan politik dan ideologi. Gramsci membedakan antara dominasi (kekerasan) dengan kepemimpinan moral dan intelektual, sehingga hegemoni tersebut berhubungan dengan mekanisme konsensus, bukan penindasan atau kekerasan terhadap kelompok masyarakat.

Pengembangan perangkat lunak perpustakaan perguruan tinggi melibatkan berbagai aktor, mulai dari programmer sebagai pembuat program awal (default) dan custom yang diambil dari tenaga Teknologi Informasi (TI) perpustakaan dan di luar perpustakaan, kepala perpustakaan sebagai pengambil kebijakan, pustakawan sebagai pengguna atau operator, dan mahasiswa sebagai pengguna akhir. Beberapa aktor tersebut mempunyai kuasa hegemonik terhadap aktor lainnya sehubungan pengetahuan yang dimilikinya. Kekuasaan hegemonik tersebut sangat berperan dalam relasi kuasa aktor perpustakaan elektronik.

Istilah "dekonstruksi" mempunyai berbagai makna, seperti penataan ulang, metode pembacaan teks, dan pengurangan atau penurunan intensitas bentuk yang sudah tersusun, sebagai bentuk yang sudah baku. Namun demikian, pengertian "dekonstruksi" lebih sering diambil dari pengertian Derrida yaitu posisi anti-esensialisme atau makna stabil. Jacques Derrida seorang filsuf Yunani kelahiran Aljazair menekankan makna dekonstruksi pada pembongkaran makna stabil, dalam hal ini makna stabil merupakan makna sementara yang selanjutnya harus dibongkar untuk mencari makna lain dibalik makna stabil tersebut. Oleh karena itu, dekonstruksi Derrida berpegang pada konsep berbagai makna. Derrida menyatakan bahwa setiap teks terdapat maknamakna yang tersembunyi di belakangnya (Siregar, 2019). Teks tersebut tidak mempunyai kemampanan makna karena teks dapat diinterpretasikan sesuai keinginan pembacanya sehingga maknanya menjadi tidak tunggal. Dekonstruksi Derrida juga sering dikaitkan dengan pembongkaran kebenaran tunggal mengingat kebenaran tersebut tidak hanya tunggal saja namun juga plural. Derrida menginginkan kebenaran itu tidak harus dibatasi dalam kebenaran tunggal, umum, dan universal, karena dalam kenyataannya kebenaran itu bersifat plural, partikular, dan relative (Turiman, 2015).

Konsep berbagai makna merupakan perlawanan dari penganut konsep oposisi biner (binary opposition), di mana konsep tersebut menyandingkan dua makna saja seperti hitam dengan putih, lelaki dengan perempuan, dan sejenisnya. Penganut konsep berbagai makna selalu mencari sesuatu dibalik makna yang dimunculkan sehingga mereka meyakini bahwa makna yang dimunculkan tersebut adalah makna sementara dan masih dapat diperdebatkan lagi. Makna yang diungkapkan dalam teks masih mempunyai makna lain yang sering disembunyikannya.

Dekonstruksi dapat terjadi di pelbagai aspek kehidupan manusia. Pengarang membuat sebuah karya untuk dinterpretasikan lagi oleh pembaca, sehingga karya tersebut masih dapat dipahami walaupun pengarangnya sudah meninggal. Dekonstruksi di bidang teknik, khususnya arsitektur dilakukan untuk membongkar permasalahan arsitektur sebelumnya agar dapat dicarikan solusinya. Dekonstruksi dalam arsitektur muncul dan berkembang tidak lepas dari proses panjang perkembangan arsitektur itu sendiri, yang juga dipengaruhi oleh kondisi sosial, budaya, ekonomi dan teknologi (Matualage et al., 2018). Dekonstruksi di bidang hukum dilakukan untuk menjamin kesetaraan dalam penegakan hukum dan mengembalikan sistem peradilan secara hakiki. Dekonstruksi di bidang politik dilakukan untuk membongkar dan sekaligus memperbaiki sistem politik dan nilai sosial. Dekonstruksi di bidang teknologi informasi dilakukan untuk menjamin kemapanan teknologi tersebut. Berdasarkan uraian di atas, dekonstruksi dapat terjadi terutama pada karya-karya yang sarat mengandung nilai-nilai dan ideologi.

Teori relasi kuasa Foucault menyingkapkan makna yang terkait dengan kekuasaan berbasis pengetahuan. Dalam relasi kuasa, bukanlah 
kekuasaan jika seseorang mengikuti perintah orang lain seperti dalam perbudakan (Rahmasari \& Nurhayati, 2019). Oleh karena itu, kekuasaan tersebut bukanlah represif yang dapat membuat seseorang mengikuti perintah orang lain secara terpaksa. Kekuasaan adalah serangkaian tindakan di atas tindakan lainnya yang tidak memberikan efek langsung pada seseorang. Teori dekonstruksi Derrida membongkar struktur kekuasaan yang bermain dalam praktik relasi kuasa. Dekonstruksi menentang nilai-nilai universal, kepastian, dan ketunggalan yang diartikan sebagai pembongkaran untuk menyempurnakan makna sebelumnya. Berdasarkan uraian tersebut, teori relasi kuasa Foucault dan dekonstruksi Derrida sangat relevan digunakan untuk membedah fenomena yang terjadi terkait dengan praktik relasi kuasa dalam pengembangan perangkat lunak open source perpustakaan perguruan tinggi di Bali.

\section{METODE PENELITIAN}

Penelitian ini menggunakan pendekatan kualitatif dengan metode kajian budaya (cultural studies). Pendekatan ini digunakan karena praktik relasi kuasa dalam pengembangan perangkat lunak open source merupakan praktik sosial yang di dalamnya tersirat praktik kekuasaan, dekonstruksi dan pemaknaan yang melandasi berbagai praksis dan gerakan aktor dalam kegiatan tersebut. Metode cultural studies meliputi metode etnografi, semiotika, dekonstruksi, dan genealogi (Piliang \& Jaelani, 2018). Metode etnografi menggunakan budaya sebagai kajiannya. Metode ini memusatkan perhatiannya untuk menemukan bagaimana berbagai masyarakat mengorgisasikan budaya mereka dalam pikiran mereka dan kemudian menggunakan budaya tersebut dalam kehidupan (Siddiq \& Salama, 2019). Metode semiotika merupakan pendekatan sistem tanda. Tanda tersebut mempunyai banyak interpretasi makna dari pembaca. Metode dekonstruksi merupakan metode kualitatif dari ilmu filsafat yang memperlihatkan hal-hal yang tersembunyi dan membongkar makna yang implisit (Bonisoli et al., 2018). Metode genealogi merupakan pendekatan historis dan metode investigasi yang menawarkan kritik terhadap suatu fenomena. Metode ini menganalisis dan membongkar hubungan antara pengetahuan, kuasa, dan subjek manusia. Sehubungan dengan itu, praktik relasi kuasa dalam penelitian ini sangat terkait dengan metode dekonstruksi dan genealogi. Metode dekonstruksi berkaitan dengan pembongkaran terhadap berbagai struktur termasuk kekuasaan, sedangkan metode genealogi berusaha menyingkapkan relasi kekuasaan pengetahuan yang melekat dalam praktik sosial, sehingga kedua metode ini sangat relevan untuk mengkaji praktik relasi kuasa dalam pengembangan perangkat lunak open source. Sehubungan dengan itu, cultural studies dalam memahami fenomena sosial budaya yang dikaji mempergunakan paradigma atau pendekatan kualitatif sebagai pendekatan utama dengan bersandar pada metode-metode: etnografi kritis, semiotik, dekonstruksi, dan metode genealogi atau arkeologi pengetahuan (Kumbara, 2018).

Subjek penelitian ini adalah Kepala Perpustakaan, Pustakawan, Tenaga TI Perpustakaan, Pemustaka, Tenaga TI Universitas, dan programmer. Objek penelitian adalah praktik relasi kuasa aktor tersebut. Pemilihan informan penelitian ini menggunakan purposive sampling. Teknik ini digunakan mengingat penelitian ini menggunakan informan yang terkait dengan perangkat lunak open source. Informan tersebut berasal dari Perpustakaan Universitas Udayana, Perpustakaan Universitas Pendidikan Ganesha, Perpustakaan Institut Seni Indonesia Denpasar, Perpustakaan Universitas Mahasaraswati Denpasar, Sekolah Tinggi Manajemen Informatika dan Teknik Komputer STIMIK STIKOM Bali. Kelima perguruan tinggi tersebut dijadikan lokus penelitian mengingat perguruan tinggi itu memperoleh peringkat 1 (satu) sampai 5 (lima) di Bali versi Webometrics. Secara keseluruhan, hubungan subjek penelitian tersebut digambarkan seperti pada gambar 1 .

Teknik pengumpulan data penelitian ini menggunakan observasi, wawancara semiterstruktur, dokumentasi, dan studi literatur. Teknik observasi dilakukan untuk 
mengumpulkan data atau fakta terkait dengan perangkat lunak open source. Teknik wawancara semi-terstruktur dilakukan mengingat pertanyaan-pertanyaan yang disampaikan kepada narasumber lebih terbuka. Pertanyaan tersebut merupakan kelanjutan dari pertanyaan terstruktur dan diharapkan dapat memperoleh pendapat atau ide narasumber secara lebih mendalam. Teknik dokumentasi digunakan untuk memperoleh dokumen atau catatan terkait dengan pengembangan perangkat lunak open source. Teknik studi literatur digunakan untuk menelusuri referensi terkait dengan penelitian ini. Analisis data menggunakan metode kajian budaya (cultural studies). Pendekatan ini digunakan karena praktik relasi kuasa dalam pengembangan perangkat lunak open source perpustakaan perguruan tinggi di Bali merupakan praktik sosial yang di dalamnya tersirat praktik kekuasaan, dekonstruksi dan pemaknaan yang melandasi berbagai praksis dan gerakan aktor dalam kegiatan tersebut. Praktik relasi kuasa dalam penelitian ini membongkar berbagai struktur termasuk kekuasaan dan menyingkapkan relasi kekuasaan pengetahuan yang melekat dalam praktik sosial.

\section{HASILDAN PEMBAHASAN}

Kekuasaan merupakan unsur yang penting dalam kehidupan masyarakat. Oleh karena itu, kekuasaan ada dalam setiap bentuk masyarakat. Kekuasaan adalah kemampuan untuk memengaruhi, mengatur pikiran atau kehendak, dan tingkah laku orang lain (Ardika et al., 2018). Sehubungan dengan hal tersebut, kekuasaan terjalin dari hubungan simetris dan asimetris antara pihak yang memiliki kemampuan untuk melancarkan pengaruh dan pihak lain yang menerima pengaruh tersebut. Kekuasaan menyebar dan meresap ke dalam seluruh hubungan sosial. Kekuasaan yang tersebar dalam masyarakat cenderung menjalin hubungan yang sering dipahami sebagai relasi kuasa.

Relasi kuasa terdiri dari kata "relasi" dan "kuasa". Menurut Kamus Besar Bahasa Indonesia, adalah hubungan; perhubungan; pertalian; dan kuasa berarti kemampuan atau kesanggupan (untuk berbuat sesuatu) (Badan Pengembangan dan Pembinaan Bahasa, 2016). Dengan demikian, relasi kuasa adalah hubungan yang didasari oleh kemampuan untuk melakukan sesuatu. Relasi kuasa dalam fenomena perangkat lunak open source perpustakaan perguruan tinggi di Bali merupakan hubungan antara kekuasaan kepala perpustakaan sebagai pucuk pimpinan perpustakaan dengan kekuasaan dari aktor lain yang saling mempengaruhi dalam rangka pelaksanaan kegiatan pengembangan perangkat lunak open source perpustakaan perguruan tinggi di Bali.

Perpustakaan elektronik perguruan tinggi di Bali lebih banyak menggunakan perangkat lunak Senayan Library Management System (SLiMS). Perangkat lunak ini merupakan perangkat lunak open source yang dapat diakses secara terbuka dan bebas biaya. Pada awalnya, SLiMS dirancang dan dibangun tanpa ada pertimbangan komersial, seperti yang disampaikan oleh SLiMS Developer sebagai berikut:

"Jadi kalau misalnya dulu saya sama Mas Ari ngembangin SLIMS kemudian saya ngasi pengumuman eh nih kita bikin software, anda mau pakek silahkan bayar saya rasa ga ada orang yang mau, ngapain gitu lo tapi justru dengan model pendekatannya open source yang didapat justru malah lebih dahsyat, kita dikenal banyak orang, orang ada trust ke kita, kita jadi punya saudara" (Wicaksono, wawancara, 20 Juni, 2019).

Perangkat lunak SliMS sebagai perangkat lunak open source membuat perangkat lunak tersebut dikenal oleh masyarakat. Wacana "gratis" yang dimunculkan oleh perangkat lunak tersebut membuat pengguna sistem menggunakannya. Pengguna mulai mengunduh, memasang dan menyesuaikan dengan kebutuhannya. Ketika proses ini dilakukan, banyak pengguna mengalami kendala teknis. Kendala teknis tersebut didiskusikan dengan pustakawan dan tenaga TI Perpustakaan. Akhirnya, kendala teknis tersebut didiskusikan dengan pembuat program 
agar memperoleh solusi yang optimal. Proses tersebut menghasilkan relasi kuasa antara pengguna sistem dengan programmer. Relasi ini bertujuan agar pengguna dapat menggunakan sistem itu secara optimal, seperti yang disampaikan oleh Kepala Perpustakaan Unmas sebagai berikut:

"Terus terang untuk perpustakaan kami walaupun online kita untuk sistem SLIMS dan sistem repository itu kami belum memiliki IT sendiri jadi dikomunikasikan dengan IT di pusat dan ditambah dengan IT luar begitu" (Gandarini, wawancara, 6 Februari, 2021).

Pernyataan informan tersebut di atas menunjukkan bahwa pengguna SliMS sangat tergantung dengan tenaga teknologi informasi (pembuat program) sehingga mereka harus melakukan hubungan dengan pembuat program. Tahapan berikutnya dalam pengembangan dan implementasi perangkat lunak open source perguruan tinggi di Bali adalah sosialisasi, uji coba, dan launching sistem. Pada tahap sosialisasi, programmer sistem default dan programmer sistem kastom memberikan pelatihan tentang cara penggunaan sistem tersebut kepada tenaga TI perpustakaan dan pustakawan. Pada tahap uji coba sistem, programmer menerima masukan dari pustakawan, tenaga TI perpustakaan dan pemustaka. Selanjutnya pada tahap launching sistem, pustakawan dan pemustaka menggunakan sistem tersebut untuk pelayanan perpustakaan secara elektronik. Berdasarkan uraian tersebut, relasi kuasa pada tahap ini melibatkan programmer sistem default, programmer sistem kastom, tenaga TI perpustakaan, pustakawan, dan pemustaka.

Proses relasi kuasa dalam pengembangan perangkat lunak open source perguruan tinggi di Bali seperti yang diuraikan tersebut di atas, menempatkan pengetahuan sebagai sarana untuk menyampaikan kepentingan. Dalam hal ini, semua aktor tersebut mempunyai pengetahuan tentang perangkat lunak open source. Walaupun pengetahuan aktor itu berbeda-beda, namun pengetahuan itu dapat saling melengkapi satu dengan yang lainnya sehingga pengembangan dan implementasi perangkat lunak open source sebagai sistem perpustakaan elektronik perguruan tinggi di Bali dapat berjalan optimal. Oleh karena itu, proses relasi kuasa tersebut menempatkan pengetahuan sebagai kekuasaan aktor. Setiap kekuasaan akan berhubungan dengan pembentukan suatu pengetahuan, dan pembentukan suatu pengetahuan dapat secara langsung membentuk hubungan kekuasaan (Pratama, 2021). Tak ada hubungan kekuasaan yang tidak terkait dengan pembentukan suatu bidang pengetahuan, serta tak ada pengetahuan yang tidak mengandaikan dan sekaligus membentuk hubungan kekuasaan (Adlin, 2016).

Pada umumnya, struktur organisasi menempatkan kekuasaan sesuai tingkatannya, dalam hal ini, semakin tinggi kedudukannya, makin besar kekuasaannya. Struktur seperti itu sering menciptakan hubungan dominatif, sehingga bentuk relasi kuasa menjadi asimetris disesuaikan dengan kedudukan aktor dalam organisasi. Namun demikian, bentuk relasi kuasa aktor dalam pengembangan dan implementasi perangkat lunak open source perguruan tinggi di Bali memperlihatkan bentuk tersendiri sesuai dengan peran atau kekuasaan aktor. Bentuk relasi kuasa tersebut dapat diuraikan kembali kedalam bingkai relasi kuasa terkait dengan relasi personal masing-masing aktor seperti terlihat pada Gambar 2.

Sesuai gambar 2, memperlihatkan relasi kuasa antara kepala perpustakaan dengan tenaga ti perpustakaan, pustakawan, tenaga ti universitas, pemustaka, dan programmer. Berdasarkan gambar 2 di atas menggambarkan relasi kuasa dalam bentuk segi lima kuasa dengan pusat pengarahnya adalah kepala perpustakaan. Kepala perpustakaan mempunyai kuasa yang lebih menonjol dibandingkan aktor lain. Walaupun Kepala Perpustakaan mempunyai kedudukan struktural yang lebih tiggi dari aktor lain, namun demikian, relasi kuasa tersebut masih dalam bentuk kesetaraan, seperti yang disampaikan oleh Kepala Perpustakaan Universitas Udayana sebagai berikut: 
"Kita sendiri yang mengajukan fiturfiturnya yang akan dibuat oleh USDI dan terus ada penambahan-penambahan dari kami... Untuk penambahan fitur-fitur dari kita jadi USDI-nya yang bagaimana caranya sistem yang ada di perpustakaan tercapai” (Sanjiwani, wawancara, 28 Desember, 2020).

Pernyataan di atas menunjukkan bahwa masing-masing aktor mempunyai pengetahuan dan kuasa sendiri tentang perpustakaan elektronik, dalam hal ini, Kepala Perpustakaan Universitas Udayana mengajukan fitur dan tenaga TI membangun sistemnya. Sementara itu, relasi kuasa dalam bentuk negosiasi diperlihatkan oleh tenaga TI Universitas Pendidikan Ganesha dengan aktor lain, sebagai berikut:

"Pembuatan sistem selalu berdiskusi dengan aktor lain. Jika ada permasalahan saya akan mengecek permasalahan pada sistem tersebut, jika bisa diperbaiki segera atau eror-nya hanya di sitaksis saya akan perbaiki, jika bermasalah pada logika atau bisnis prosesnya maka akan didiskusikan dengan pustakawan, UPT TIK, dan tim" (Mahedy, wawancara 9 Pebruari 2021).

Sementara itu, bentuk relasi kuasa hegemonik dan counter-hegemonic diperlihatkan oleh Programmer, seperti pada Gambar 3.

Sesuai gambar 3, relasi kuasa dalam bentuk segi empat kuasa dengan pusat pengarahnya adalah programmer. Secara keseluruhan, relasi kuasa tersebut adalah seimbang Namun demikian, relasi kuasa tersebut bersifat negosiatif, hegemonik dan counter-hegemonic, seperti yang disampaikan pengembang sistem kastom sebagai berikut:

"O, belum Pak karena perlu diedit dulu atau di-customize dulu sesuai permintaan dari perpustakaan. Saya kan memperbaiki sistem jadi sesuai dengan keinginan perpustakaan" (Wirayuda, wawancara, 9 Desember, 2020)
Pernyataan di atas menunjukkan bahwa pengguna tetap berhubungan dengan pengembang dalam rangka optimalisasi pemanfaatan software. Semua petunjuk pengembang tersebut disetujui dan dijalankan oleh pengguna secara sukarela. Sehubungan dengan itu, bentuk relasi kuasa antara pengembang dengan pengguna tersebut adalah hegemonik. Bentuk hegemonik tersebut terkait dengan konsensus antara pengembang dan pengguna sistem.

Berdasarkan uraian tersebut, dapat dikatakan bahwa bentuk relasi kuasa dalam pengembangan perangkat lunak open source perpustakaan perguruan tinggi di Bali adalah kesetaraan, negosiasi, hegemoni, dan counterhegemony. Bentuk kesetaraan dan negoisasi ditunjukkan oleh Kepala Perpustakaan dengan aktor lain, sedangkan bentuk hegemoni dan counter-hegemony ditunjukkan oleh programmer dengan aktor lain. Dalam penelitian ini, bentuk kesetaraan dan negosiasi berhubungan dengan pemikiran Foucault, sedangkan bentuk hegemoni dan counterhegemony berhubungan dengan pemikiran Gramsci. Kesetaraan mengacu kepada setiap aktor mempunyai pengetahuan yang dijadikan sebagai kekuasaan dalam relasi kuasa, sehingga kekuasaan bekerja melalui pengetahuan. Kamahi (2017) mengatakan bahwa karya Foucault dalam tema kegilaan, disiplin, dan seksualitas membicarakan beroperasinya jalinan antara kekuasaan dan pengetahuan. Karya tersebut menjelaskan bagaimana kekuasaan bekerja. Kekuasaan tidak dipahami secara negatif, melainkan produktif. Kekuasaan menyebar dan mengalir dalam praktik pendisiplinan. Bentuk hegemoni dan counterhegemony terkait pemikiran Gramsci mengingat didalamnya mengandung makna konsensus atau penerimaan ideologi dari kelas tertentu secara sukarela. Hegemoni dalam pengertian Gramsci adalah sebuah konsensus dimana ketertundukan diperoleh melalui penerimaan ideologi kelas yang menghegemoni oleh kelas yang terhegemoni (Siswati, 2017).

Secara etimologis, kata "ideologi" berasal dari bahasa Perancis, yaitu: ideo, yang berarti ide, cita-cita, gagasan, pemahaman, 
memandang, atau melihat, dan kata logia atau logie, yang berarti logika atau alasan. Jadi secara bahasa arti ideologi adalah sekumpulan ide atau gagasan yang menjadi panduan bagi kelompok manusia untuk mencapai tujuan tertentu. Sehubungan dengan itu, ideologi aktor pengembangan perangkat lunak perpustakaan perguruan tinggi di Bali merupakan pandangan yang dijadikan landasan untuk merealisasikan keinginan aktor, sehingga ideologi tersebut berpotensi melahirkan dominasi dan subordinasi dalam isu pengembangan tersebut. Pada saat ini, konsep ideologi itu berkaitan erat dengan pengetahuan aktor yang diyakini kebenarannya dan diaplikasikan dalam praktikpraktik perpustakaan elektronik. Ideologi dapat membentuk kepercayaan diri aktor dalam merepresentasikan keinginannya.

Pengembangan perangkat lunak open source dapat dijadikan ajang kontestasi ideologi aktor, mengingat di dalam praktik relasi kuasa itu bermain berbagai ideologi aktor. Seorang Programmer membangun suatu perangkat lunak tiada lain sebagai sebuah pertunjukan ideologi yang dipertontonkan kepada masyarakat melalui setiap tindakannya. Dengan demikian, ideologi dalam kaitan ini mengandung pengertian sekumpulan ide yang diartikulasikan oleh programmer untuk melihat realitas dalam praktik budaya dan mempunyai pengaruh yang mengikat pada suatu tatanan sosial. Oleh karena itu, kajian tentang ideologi aktor pengembangan perangkat lunak open source perguruan tinggi di Bali merupakan kajian tentang strategi aktor dalam membangun dan mempertahankan hubungan kesetaraan dan mungkin juga hegemoni dan negosiasi di antara aktor tersebut.

Nilai-nilai ideologi dapat digunakan untuk mengendalikan semua aktor yang terlibat dalam pengembangan perpustakaan elektronik perguruan tinggi di Bali. Ketika di awal, programmer membicarakan ide pengembangan perangkat lunak open source kepada programmer lain, pada saat itu ideologi sudah bermain. Para pengembang program menyepakati bahwa pengembangan perangkat lunak menggunakan konsep open source, seperti yang disampaikan informan sebagai berikut:
"SLIMS juga kita inginkan seperti idealisme kita jadi open source dan ternyata pendekatan open source ini justru lebih pas untuk SLIMS" (Wicaksono, wawancara, 20 Juni, 2019)

Pernyataan informan tersebut menunjukkan ideologi yang dimunculkan dalam pernyataan tersebut adalah ideologi open source. Di samping itu, mengingat perangkat lunak itu dikerjakan secara bersama-sama maka ideologi lain yang muncul adalah ideologi berbagi atau gotong royong. Ideologi berbagi terkait dengan pengembangan perangkat lunak secara bersama-sama.

Penggunaan perangkat lunak tersebut di perpustakaan dimulai oleh ide kepala perpustakaan yang menganggap perangkat lunak itu tidak berbayar (gratis) dan dapat dijadikan sebagai sistem perpustakaan elektronik. Kepala perpustakaan mengajak aktor lain untuk menyetujui menggunakan software tersebut. Sehubungan dengan itu, di awal penggunaannya, perangkat lunak open source perpustakaan perguruan tinggi di Bali melahirkan ideologi gratis dan sistem perpustakaan elektronik. Perangkat lunak open source itu tidak selamanya gratis karena ketika perpustakaan tidak mempunyai tenaga yang mampu mengubah perangkat lunak itu sesuai dengan kebutuhannya, maka diperlukan hubungan dengan aktor lain yang mampu mengerjakannya. Fenomena seperti ini sangat sesuai dengan model bisnis open source, seperti yang disampaikan oleh informan berikut:

"Iya betul dan itu memang model bisnis open source tuh begitu jadi bukan softwarenya yang dijual tapi jasa tambahannya misalnya mau di-custom, tampilan, fitur atau pelatihan atau support maintenance dll... Kita di developer di tim pengembangan SLIMS kita punya keyakinan ketika kita mengembangkan kita ga mikir uang bukan berarti kita ga butuh uang, kita berkeyakinan bahwa nanti kalau ini sukses uang itu akan datang dari sini" (Wicaksono, wawancara 20 Juni 2019). 
Pernyataan informan di atas menunjukkan perpustakaan mengeluarkan berbagai biaya terkait dengan modifikasi perangkat lunak open source. Dengan demikian, pada tahap implementasi perangkat lunak ini terlihat ideologi perpustakaan elektronik dan kapitalis mulai bekerja. Kontestasi ideologi terjadi lagi ketika perangkat lunak itu diimplementasikan. Pustakawan sebagai operator sistem berhadapan dengan pemustaka sebagai pengguna sistem. Mereka menggunakan ideologinya masingmasing dalam menjalankan sistem tersebut. Pustakawan menganggap bahwa sistem tersebut dijalankan sesuai dengan prinsip-prisip kepustakawanan, sedangkan pemustaka menganggap bahwa sistem itu sebagai sarana pencarian informasi untuk memenuhi kebutuhannya. Oleh karena itu, ideologi yang bekerja pada tahap ini adalah ideologi kepustakawanan dan sistem perpustakaan elektronik.

Berdasarkan uraian tersebut, dapat dikatakan bahwa praktik relasi kuasa dalam pengembangan perangkat lunak open source perpustakaan perguruan tinggi di Bali melahirkan ideologi gratis, kapitalis (ekonomi), kepustakawanan, dan sistem perpustakaan elektronik. Ideologi ini berkontestasi dalam praktik relasi kuasa, dalam hal ini, praktik relasi kuasa diselubungi oleh kepentingan para aktor, dan ideologi aktor bermain dalam praktik tersebut. Hal ini wajar mengingat ideologi tersebut dapat merepresentasikan makna tentang suatu konsep, paham, dan cara seseorang berpikir, bersikap, dan bertindak.

Relasi kuasa pengembangan perangkat lunak open source perguruan tinggi di Bali memberikan implikasi pada berbagai aspek sosial, ekonomi, dan budaya. Secara umum, pembicaraan perangkat lunak open source biasanya terkait dengan hal-hal teknis sistem tersebut. Namun demikian, perangkat lunak open source dapat diinterpretasi melalui aspek lainnya, seperti aspek sosial-budaya. Kajian aspek sosial-budaya terhadap perangkat lunak open source terkait dengan pemanfaatan perangkat lunak tersebut di masyarakat.

Perangkat lunak open source merupakan produk budaya yang berkontribusi terhadap peradaban manusia. Pengembangan perangkat lunak open source perpustakaan perguruan tinggi menyebabkan perpustakaan mengganti layanan konvensional ke lebih modern, sehingga kita mengenal istilah perpustakaan elektronik, perpustakaan digital, dan perpustakaan 4.0. Semuanya itu tidak lepas dari peranan perangkat lunak open source. Di samping itu, kehadiran perangkat lunak open source dapat mengembalikan budaya berbagi (sharing) dan gotong royong di tengah masyarakat, di mana saat ini, budaya berbagi dan gotong royong mulai tergerus dan terancam oleh budaya global.

Pengembangan perangkat lunak open source memberikan dampak ekonomi bagi pengembang dan penggunanya. Perangkat lunak open source memberikan label atau brand tersendiri kepada pengembang yang dapat memberikan nilai lebih (added value) di tengah masyarakat. Pengembang mulai dikenal, mendapatkan upah, dan prestise yang dapat meningkatkan kariernya di masa mendatang. Begitu juga dengan penggunanya. Pengguna mendapatkan sesuatu yang sama dengan pengembang ketika pengguna memahami dan mengimplementasikan perangkat lunak open source tersebut.

Perangkat lunak open source memberikan implikasi sosial khususnya bagi perpustakaan, dan pemustaka. Kehadiran perangkat lunak open source sebagai sistem perpustakaan elektronik atau digital menyebabkan mediatisasi perpustakaan sehingga perpustakaan menjadi lebih dikenal masyarakatnya. Mediatisasi perpustakaan dapat menjangkau pengguna global, seperti yang disampaikan oleh pustakawan ISI Denpasar sebagai berikut:

"Layanan kita menjadi global dengan memberikan link ke berbagai sumber informasi yang berguna untuk bahan referensi, sehingga memberikan kemudahan akses bagi pemustaka, juga ada konten digital yang dapat didownload kapan saja oleh pemustaka" (Darmiyasa, wawancara, 8 Maret, 2021). 
Namun demikian, aspek konvensional perpustakaan juga menjadi terpinggirkan (termarginalisasikan) dengan adanya perangkat lunak tersebut. Koleksi tercetak dan cara-cara layanan konvensional mulai ditinggalkan pengguna. Di samping itu, kehadiran sistem perpustakaan elektronik menyebabkan perilaku pencarian pengguna perpustakaan mulai berubah. Pengguna lebih banyak mengakses koleksi elektronik dan layanan online melalui sistem tersebut. Komunikasi tatap muka antara pemustaka dengan pustakawan sudah jarang dilakukan, mereka berkomunikasi melalui fitur yang disediakan oleh sistem dan media sosial, seperti yang disampaikan oleh pemustaka Universitas Udayana sebagai berikut.

"Dampaknya saya interaksinya dengan pribadinya dibandingin mungkin agak berkurang saya bisa langsung lihat nyari tanpa bantuan mereka" (Agnesia, wawancara, 28 Desember, 2020).

Pemustaka melalui fasilitas atau fitur yang disediakan system dapat melakukan pencarian informasi, perpanjangan buku, dan sebagainya tanpa bantuan pustakawan. Gaya hidup (life style) pemustaka juga mulai berubah. Pemustaka tidak lagi mengakses informasi melalui komputer yang tersedia di perpustakaan, namun juga laptop dan teknologi mobile seperti smartphone mengingat informasi itu sudah dapat diakses kapan dan di mana saja tanpa perlu datang ke perpustakaan. Pemustaka seperti ini sering disebut pemustaka digital natives, pemustaka yang menginginkan segala sesuatunya serba instan yang tersedia di internet. Di samping implikasi yang telah diuraikan di atas, secara teoritik, hasil penelitian dalam teori relasi kuasa dan pengetahuan Michel Foucault dan teori dekonstruksi Derrida berimplikasi pada pengembangan pengetahuan dimana kajian yang bersifat positivistik dapat dikaji dengan kajian budaya (cultural studies).

\section{E. KESIMPULAN}

Relasi kuasa dalam pengembangan perangkat lunak open source perpustakaan perguruan tinggi di Bali menempatkan pengetahuan sebagai kekuasaan aktor. Pengembangan perangkat lunak open source perguruan tinggi di Bali memuat berbagai konsep pengetahuan sehingga memiliki kekuasaan yang sangat besar. Dengan demikian, secara umum, konsep kuasa pengetahuan Foucault dapat diimplementasikan dalam penelitian ini. Penempatan pengetahuan sebagai kekuasaan aktor dapat membentuk hubungan kesetaraan, negoisiatif, hegemoni dan counterhegemony. Hubungan tersebut bekerja berbagai ideologi aktor di dalamnya seperti ideologi open source, kepustakawanan, sistem perpustakaan elektronik, gratis, dan kapitalis. Disamping itu, relasi kuasa pengembangan perangkat lunak open source perguruan tinggi di Bali memberikan dampak positif terkait dengan aspek sosial, ekonomi, dan budaya masyarakat. Perangkat lunak open source sebagai produk budaya memberikan label atau brand tersendiri yang dapat mendukung pencapaian kesehjateraan masyarakat pengguna melalui sistem yang lebih modern dan bernilai guna. Hasil penelitian ini diharapkan dapat dijadikan referensi penelitian selanjutnya, yaitu dikaji dari sisi positivistic, seperti penelitian tentang aspek teknis sistem menggunakan berbagai teori kritis dengan pendekatan kajian budaya. Oleh karena itu, penelitian sejenis ini sangat perlu dilakukan dalam rangka pengembangan ilmu kajian budaya di masa mendatang.

\section{DAFTAR PUSTAKA}

Adlin, A. (2016). Michael Foucault: Kuasa/pengetahuan, rezim (Kebenaran), parrhesia. Jurnal Aqidah dan Filsafat Islam, 1(1), 13-26. https:// journal.uinsgd.ac.id/index.php/jaqfi/article /view/1694/1140

Akhlis, I. (2013). Pemanfaatan perangkat lunak open source untuk menunjang kegiatan akademik di SMA Negeri 12 Semarang. 11(2), 127-132. https://journal.unnes.ac.id/ nju/index.php/rekayasa/article/view/10318 $/ 6417$ 
Angreni, D. S., \& Prastyaningsih, Y. (2019). Analisis evolusi ekosistem perangkat lunak open source: Tinjauan pustaka sistematis. ScientiCO : Computer Science and Informatics Journal, 2(1), 29-38. https://doi.org/10.22487/j26204118.2019. v2.i1.13069

Ardika, I. W., Wiguna, IGN. T., \& Srijaya, I. W. (2018). Sapatha dalam relasi kuasa dan pendisiplinan pada masyarakat Bali kuno abad IX-XIV masehi. Berkala Arkeologi, 38(1), 1-16. https://doi.org/10.30883/ jba.v38i1.231

Badan Pengembangan dan Pembinaan Bahasa. (2016). Kamus besar bahasa Indonesia. https://kbbi.kemdikbud.go.id/entri/relasi

Bonisoli, L., Galdeano-Gómez, E., \& PiedraMuñoz, L. (2018). Deconstruction: The qualitative methodology for the analysis of sustainability assessment tools of agrisystem. MethodsX, 5(2018), 635-638. https://doi.org/10.1016/j.mex.2018.06.003

Gozali, F., \& Lo, B. (2012). Pemanfaatan teknologi open source dalam pengembangan proses belajar jarak jauh di perguruan tinggi. Jurnal Nasional Pendidikan Teknik Informatika (JANAPATI), 1(1), 47-57. https://doi.org/ 10.23887/janapati.v1i1.9767

Kähkönen, A.-K. (2014). The influence of power position on the depth of collaboration. Supply Chain Management: An International Journal, 19(1), 17-30. https://doi.org/10.1108/SCM-03-20130079

Kamahi, U. (2017). Teori kekuasaan michel foucault: Tantangan bagi sosiologi politik. Jurnal Al-Khitabah, III(1), 117-133. http://journal.uin-alauddin.ac.id/ index.php/Al-Khitabah/article/view/2926/ 2802

Kumbara, A. A. N. A. (2018). Genealogi teori dan metodologi di cultural studies. Jurnal Studi Kultural, III(1), 35-46. https://erepo.unud.ac.id/id/eprint/17178/1/ e9bec74e737006a89d5dd97a0ad0fb59.pdf

Malik, A. (2013). Revolusi gutenberg (makna penemuan mesin cetak bagi kemajuan peradaban manusia: Dari tradisi lisan ke tulisan). Jurnal Komunikasi, 2(2), 1-5. https://doi.org/10.30656/lontar.v2i2.342

Matualage, G., Tungka, A., E., \& Rompas, L., M. (2018). Perancangan perpustakan digital di kota Manado arsitektur dekonstruksi. Jurnal Arsitektur Daseng Unsrat, $\quad 7(2), \quad 60-69$. https://ejournal.unsrat.ac.id/index.php/das eng/article/view/20833/pdf

Mukhlis. (2016). Eksplorasi model pengembangan perpustakaan digital di perpustakaan UIN Sunan Kalijaga Yogyakarta Tahun 2014-2015. Libria, 8(1), 69-94. https://jurnal.ar-raniry.ac.id/ index.php/libria/article/view/1224/918

Müller, M., Vorraber, W., \& Slany, W. (2019). Open principles in new business models for information systems. Journal of Open Innovation: Technology, Market, and Complexity, 5(1), 1-13. https://doi.org/10.3390/joitmc5010006

Piliang, Y. A., \& Jaelani, J. (2018). Teori budaya kontemporer: Penjelajahan makna \& tanda. Aurora.

Pratama, R. A. (2021). Kekuasaan, pengetahuan, dan hegemoni bahasa dalam perspektif Michele Foucault dan Francis Bacon. Jurnal Filsafat Indonesia 4(1), 33-43. http://dx.doi.org/10.23887/jfi.v4i1. 30543

Rahmasari, G., \& Nurhayati, I. K. (2019). Strategies in power relations in a fictional work: A foucauldian analysis. Teknosastik, 17(2), 19-24. https://doi.org/10.33365/ ts.v17i2.301

Siddiq, M., \& Salama, H. (2019). Etnografi sebagai teori dan metode. Kordinat, XVIII(1), 23-48. https://doi.org/10.15408/ kordinat.v18i1.11471

Siregar, M. (2019). Kritik terhadap teori dekonstruksi derrida. Journal of Urban Sociology, 2(1), 65-75. https://doi.org/ 10.30742/jus.v2i1.611

Siswati, E. (2017). Anatomi teori hegemoni antonio gramsci. Jurnal Translitera, 5, 11-33. https://doi.org/10.35457/ translitera.v5i1.355 
Suhartika, I., \& Darmana, K. (2018). Dibalik maraknya penggunaan software open source berbasis web di perpustakaan perguruan tinggi di Bali. Sunari Penjor: Journal of Anthropology, 2(1), 74-80. https://doi.org/10.24843/SP.2018.v2.i01.p 06

Turiman, T. (2015). Metode semiotika hukum Jacques Derrida membongkar gambar lambang negara Indonesia. Jurnal Hukum \& Pembangunan, 45(2), 308-339. https://doi.org/10.21143/jhp.vol45.no2.6
Undang-Undang Republik Indonesia Nomor 43 Tahun 2007. (2007). Undang-Undang Republik Indonesia Nomor 43 Tahun 2007. Lembaran Negara Republik Indonesia Tahun $2007 \quad$ Nomor 129. https://www.perpusnas.go.id/1awdetail.php?lang=id\&id=170920114322Ir9 g6HhRuc 


\section{DAFTAR GAMBAR}

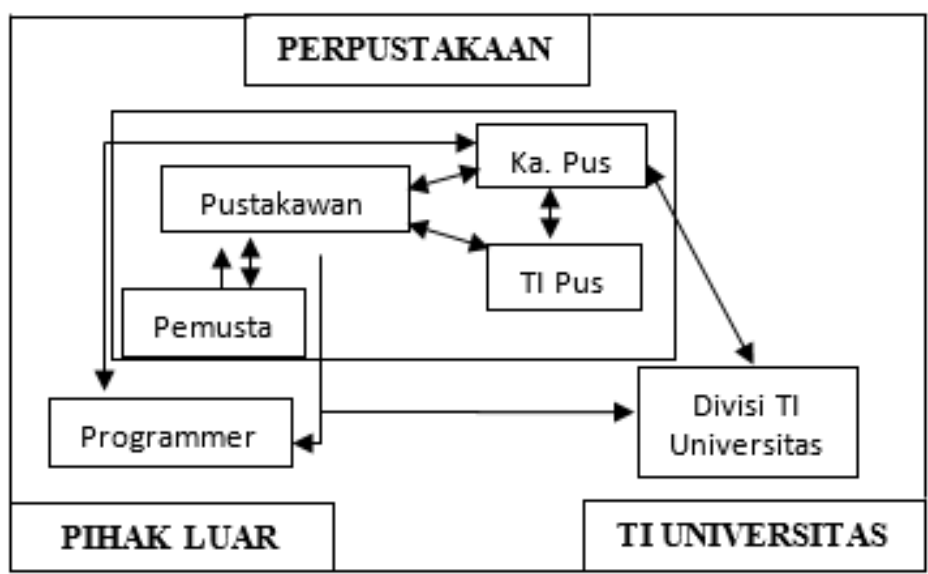

Gambar 1. Subjek Penelitian (Sumber: Hasil penelitian, 2020)

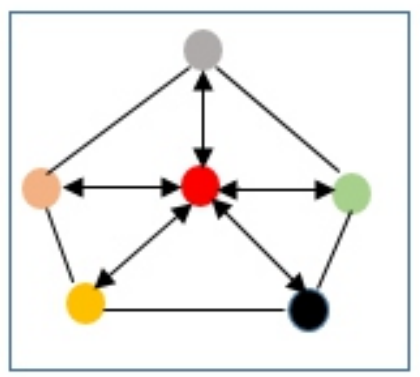

Keterangan:

- Kepala Perpustakaan

- Tenaga TI Perpustakaan

- Pustakawan

Tenaga TI Universitas

- Programmer

Pemustaka

Gambar 2: Bentuk Relasi Kuasa antara Kepala Perpustakaan dengan Aktor Lain (Sumber: Hasil penelitian, 2020)

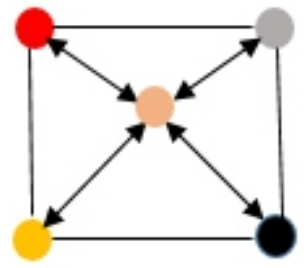

Keterangan:

- Kepala Perpustakaan

- Tenaga TI Perpustakaan

Pustakawan

- Tenaga TI Universitas

- Programmer

Gambar 3: Bentuk Relasi Kuasa antara Programme dengan Aktor Lain

(Sumber: Hasil penelitian, 2020) 